УДК 37.1

DOI 10.11603/me.2414-5998.2020.4.11650

\author{
А. В. Вихрущ \\ ORCID https://orcid.org/0000-0002-1982-0768 \\ ResearcherID I-9562-2017 \\ Т. В. Яблонь \\ ORCID https://orcid.org/0000-0003-2612-2164 \\ I. Д. Драч \\ ORCID https://orcid.org/0000-0001-7198-5546
}

Тернопільський національний медичний університет імені І. Я. Горбачевського МОЗ Украӥни

\title{
ДІТИ $З$ ОСОБЛИВИМИ ПОТРЕБАМИ В УМОВАХ РЕФОРМУВАННЯ СИСТЕМИ МІСЦЕВОГО САМОВРЯДУВАННЯ
}

\author{
A. V. Vykhrushch, T. V. Yablon, I. D. Drach \\ I. Horbachevsky Ternopil National Medical University \\ CHILDREN WITH SPECIAL NEEDS IN THE CONDITIONS OF \\ REFORMING THE SYSTEM OF LOCAL GOVERNMENT
}

\begin{abstract}
Анотація. Рівень розвитку суспільства, досягнення в утвердженні засад демократії та гуманізму можна оцінити за ставленням до дітей з особливими потребами. Якщо в минулі роки турбота про таких громадян здебільшого мала декларативний характер, то в даний час стаємо свідками системного вирішення проблем, які накопичувалися десятиліттями. Це обумовлено змінами в органах управління, прагненням досягти європейських стандартів, необхідністю використання можливостей кожної особистості. Аналіз нормативних документів, результатів наукових досліджень дозволяє зробити висновок про необхідність уточнення системи базових понять, узагальнення регіонального досвіду, вивчення переваг і недоліків діяльності органів місцевого самоврядування.
\end{abstract}

Ключові слова: виховання; діти з особливими потребами; управління.

Abstract. The level of development of society, achievements in establishing the principles of democracy and humanism can be assessed by the attitude towards children with special needs. If previously the care of such citizens was mostly declarative, now we see a systematic solution to problems that have accumulated over the decades. This is due to changes in government, the desire to achieve European standards, and the need to use the capabilities of each individual. The analysis of normative documents and results of scientific researches allows concluding the necessity of specification of the basic concepts' system, the generalization of regional experience, and studying of advantages and lack of local governments' activity.

Key words: education; children with special needs; management.

Вступ. 3 кожним роком зростає увага до питань інклюзивної освіти. Важливо, що ця проблема стає пріоритетною на рівні державних інституцій. Згідно з даними Міністерства освіти України, на початку 2019 р. в інклюзивних класах навчалося понад 12 тис. дітей, а у 2020 р. ця цифра досягла майже 20 тис. У цьому році уряд спрямував понад 504 млн гривень для навчання учнів з особливими потребами. Сьогодні приблизно у 35 \% закладів середньої освіти організовано інклюзивне навчання. 20 листопада 2020 р. для громадського обговорення запропоновано нову редакцію Положення про спеціальну школу. Інклюзивне навчання розглядається як система освітніх послуг, гарантованих державою, що базується на принципах недискримінації,

() А. В. Вихрущ, Т. В. Яблонь, І. Д. Драч врахування багатоманітності людини, ефективного залучення та включення до освітнього процесу всіх його учасників. Міністерство освіти і науки розробило проєкт Національної стратегії розвитку інклюзивної освіти на 2020-2030 роки та План заходів з її реалізації [4]. Підкреслено, що впродовж останніх років у нашій країні активно розвивається інклюзивне навчання з метою створення єдиних підходів у системі освіти, де кожна дитина буде охоплена навчанням та зможе реалізувати свій потенціал. Відзначимо системний підхід до вирішення питання: оцінка проблеми; створення умов для навчання в районах або об’єднаних громадах кожній особі; підвищення рівня підготовленості педагогічних працівників для задоволення потреб дітей; удосконалення механізму фінансування осві- 
ти; забезпечення в закладах освіти умов для здобуття якісної освіти; створення цілісної законодавчої бази у сфері інклюзивної та спеціальної освіти; забезпечення підготовки педагогічних працівників та засобів для навчання здобувачів освіти; систематичне забезпечення архітектурної доступності; створення безпечного та інклюзивного освітнього середовища. Зазначено, що станом на вересень 2020 р. відкрито 633 інклюзивно-ресурсні центри, які прийшли на заміну психолого-медико-педагогічним консультаціям (ПМПК). Наявність персональних асистентів сприяє якісно вищому рівню освіти дітей з особливими потребами. Затвердження програми підвищення кваліфікації педагогічних працівників інклюзивно-ресурсних центрів відповідно до Концепції «Нової української школи» (наказ МОН України від 13.01.2020 р.) сприятиме підвищенню якості виховного процесу.

В останні роки питання інклюзивної освіти поступово стає одним із пріоритетних у педагогічній науці. Підкреслимо значимість досліджень Л. Будяк, О. Гноєвської, І. Демченко, I. Кузави, І. Малишевської, Л. Перхун, І. Садової, М. Чайковського, М. Швед, 3. Шевців.

В умовах пандемії особливої ваги набуває діяльність автоматизованого інклюзивного ресурсного центру «Україна. Інклюзія» (https://ircenter.gov.ua).

У той же час вивчення думки експертів дозволяє виокремити значну кількість проблем, які необхідно вирішувати, починаючи 3 організації професійної підготовки майбутніх лікарів, учителів, асистентів, психологів і завершуючи системою підвищення кваліфікації, розвитку педагогічної культури батьків.

Важливість теми обумовлена реформуванням системи місцевого самоврядування, досвідом, властивим для громадських, релігійних організацій.

Мета статті - розглянути особливості навчання дітей з особливими потребами, регіональні тенденції управління виховним процесом в умовах реформування системи місцевого самоврядування.

Теоретична частина. Для розуміння закономірностей досліджуваної проблеми доцільно розглянути суть головних понять. В одній $з$ наших попередніх робіт ми довели, що навіть визначення базового поняття «здоров'я» інтерпретується 3 діаметрально протилежних позицій [1].

На думку О. А. Федько, дослідники виокремлюють найбільш типові елементи визначення здоров'я: 1. Нормальне функціонування організму на всіх рівнях його організації (органів, гістологіч- них, клітинних і генетичних структур, нормальний перебіг фізіологічних та біохімічних процесів, що сприяють індивідуальному виживанню й відтворенню). 2. Динамічна рівновага організму та його функцій з навколишнім середовищем. 3. Здатність до повноцінного виконання основних соціальних функцій, участь у соціальній діяльності та суспільно корисній праці. 4. Здатність організму пристосовуватися до постійно змінюваних умов у навколишньому середовищі, здатність підтримувати сталість внутрішнього середовища організму, забезпечуючи нормальну та різнобічну життєдіяльність і збереження живого начала в організмі. 5. Відсутність хвороби, хворобливих станів, хворобливих змін. 6. Повне фізичне, духовне, розумове й соціальне благополуччя [6]. Це важливо, оскільки без розуміння суті здоров'я важко говорити про захворювання.

На жаль, інклюзивне навчання не стало винятком. Наприклад, різноплановість підходів у нормативних документах щодо визначення суті інклюзивного навчання потребує подальших дискусій. Розглянемо декілька прикладів. Традиційно інклюзивне навчання визначається як система освітніх послуг, гарантованих державою, що базується на принципах недискримінації, врахування багатоманітності людини, ефективного залучення та включення до освітнього процесу всіх його учасників. Зауважимо, що, згідно з вимогами до дефініцій заперечення, в цьому випадку поняття «недискримінації» $€$ неприпустимим. Це очевидно, оскільки, дотримуючись такого підходу, перелік характеристик може бути продовжений на декілька сторінок. Такі складові, як «система освітніх послуг», «врахування багатоманітності людини», «ефективне залучення та включення до освітнього процесу всіх його учасників», належать до загальних характеристик функціонування освітніх систем.

Дещо краще визначення сформульоване для особи з особливими освітніми проблемами. На думку авторів нормативних документів, це насамперед особа, яка потребує додаткової постійної чи тимчасової підтримки в освітньому процесі з метою забезпечення її права на освіту. Хоча проблемою цього визначення $є$ можливість включення в цей перелік неуспішних учнів, які через відсутність мотивації не відповідають вимогам школи.

Дослідники підкреслюють п'ять важливих відмінностей між поняттями «інтеграція» й «інклюзія»: інтегральне навчання ефективне тільки для частини дітей, а інклюзія передбачає доступність 
освіти для всіх; у першому випадку діти підпорядковані загальним стандартам, а в другому - навчання адаптується до потреб дитини; включення в єдину систему дозволяє уникнути дискримінації, на відміну від спеціалізованих закладів; інклюзивна освіта передбачає поглиблену спеціалізовану підготовку педагогів; інклюзивна освіта включає взаємне навчання, що важливо для всіх учасників навчального процесу [5].

Важливість успішного вирішення проблеми інклюзивної освіти стає очевидною в контексті аналітичних зарубіжних документів. Так, 10 липня 2008 р. у Варшаві, за прикладом інших країн (Швеція - 1999 р., Ізраїль - 2000 р., Тайвань - 2003 р., арабські країни - 2004 р.) опубліковано «Рапорт про інтелектуальний потенціал Польщі» [7]. Серед конкретних рекомендацій для поліпшення ситуації було виокремлено 7 пріоритетів, такі, як: комплексна і ефективна прородинна політика, підвищення якості навчання, спрямованість шкільництва на потреби ринку праці, активність старших людей, синергія світу науки, бізнесу і культури, підвищення якості права, регулярне вимірювання показників інтелектуального капіталу. Досвід наступних років довів, що ця програма неухильно й системно виконувалася. Зокрема, на початку була проведена велика роз'яснювальна робота, починаючи від економічної доцільності й закінчуючи методичними посібниками для органів місцевого самоврядування щодо впровадження. Розглянемо окремі приклади. Найбільш кардинальною та дієвою програмою, яка водночас викликала і дискусії, і всенародну підтримку, став документ 2016 р. із красномовною назвою «Родина 500+». Суть програми зрозуміла. На кожну дитину до 18 років, незалежно від сімейних доходів, держава щомісяця виплачує 500 злотих [2].

Особливу увагу зарубіжні автори звертають на підвищення рівня психологічної культури батьків, насамперед, на поняття вигорання батьків дітей 3 особливими потребами. Вивчення думки батьків дітей з аутизмом і синдромом Дауна дозволило виокремити такі аспекти, як: втома, викликана неперервною опікою; почуття самотності; відчуття неможливості значимих змін у житті; безнадія; відсутність умінь і знань на тему виховання хворої дитини; відповідальність за долю дитини; нерозуміння з боку відповідних інституцій; неясність щодо можливостей дитини; негативна атмосфера в домі; небажання віддати дитину у відповідні заклади і докори сумління за такі думки; резигнація; фізична втома; фрустрація. Підкреслимо одну важливу особливість. Кількість проблем значно перевищує кількість порад щодо полегшення (навіть не вирішення) проблеми. Серед них: групи самодопомоги, індивідуальна терапія, інформування батьків [8].

Для вирішення аналогічних проблем в Україні важливо узагальнити досвід організації навчання дітей з особливими потребами в окремих регіонах, що особливо актуально в контексті реформування органів місцевого самоврядування. Наприклад, до системи органів, які забезпечують формування інклюзивного освітнього середовища на Чортківщині, належать Комунальна установа «Інклюзивно-ресурсний центр» Чортківської районної ради Тернопільської області, Чортківський міський комунальний центр комплексної реабілітації осіб 3 інвалідністю «Дорога в життя» з відділенням денного перебування, благодійна організація «Дім милосердя», створена з ініціативи та за підтримки Бучацької єпархії УГКЦ, спеціалізована група дошкільного навчального закладу № 5, громадська організація батьків дітей і осіб з інвалідністю та осіб з інвалідністю «Лебедята».

3 метою напрацювання ефективних шляхів вдосконалення інклюзивної освіти на території Чортківського району ми підготували «Звернення до експертів» - фахівців, професійна чи громадська діяльність яких тісно пов'язана із забезпеченням інклюзивної складової. Було запропоновано відповісти на ряд запитань, які окреслюють проблемні питання впровадження інклюзивної складової на Чортківщині: 1. 3 якими найбільшими труднощами в роботі під час забезпечення інклюзивної складової Вам довелося зустрітися? 2. Яких заходів доцільно було б вжити органам центральної влади для забезпечення рівних можливостей осіб з особливими потребами? 3. Що б Ви запропонували вдосконалити для батьків і дітей на місцевому рівні? 4. Ваші побажання для новообраних депутатів у контексті сучасних вимог інклюзивної освіти. 5. Які зміни необхідно провести для підвищення кваліфікації фахівців з питань інклюзивної освіти?

Розглянемо окремі аспекти проблеми. Зокрема, даючи відповідь на запитання «3 якими найбільшими труднощами в забезпеченні інклюзивної складової Вам довелося зустрітися?», директор комунальної установи «Інклюзивно-ресурсний центр» Чортківської районної ради Тернопільської області С. В. Хом’як виокремила такі труднощі: 
1. Архітектурна недоступність закладів освіти для забезпечення максимальної ефективності освітнього процесу. 2. Професійна некомпетентність вчителів масової школи у роботі з дітьми з особливими освітніми потребами. 3. Негативне ставлення батьків здорових дітей до організації інклюзивної освіти. 4. Академічна перевантаженість навчальних програм, які важко адаптувати до потреб дитини з особливими освітніми потребами. 5. Недостатність навчальної та методичної літератури для навчально-виховного процесу дітей з особливими освітніми потребами (підручників, посібників, рекомендованих Міністерством освіти і науки України).

Начальник відділу освіти Чортківської районної державної адміністрації Тернопільської області I. М. Гулька вказала на такі труднощі: 1 . Недостатня кількість фахівців, оскільки мало молодих людей вибирають спеціальність дефектолога, реабілітолога, психолога. 2. Спротив окремих педагогічних працівників щодо впровадження інклюзивного навчання в школах: вчителі боялися переосмислити власні педагогічні компетентності й дійти висновку, що бути вчителем означає самому навчатися упродовж життя. 3. Недофінансування закладів освіти, адже для впровадження інклюзії потрібно облаштувати заклад згідно з державними будівельними нормами.

Серед основних труднощів у роботі під час забезпечення інклюзивної складової, з якими зустрілася голова правління благодійної організації «Дім милосердя» Т. Є. Дубина: 1. Відсутність інклюзивно-ресурсних центрів (на Чортківщині такий центр було відкрито лише у 2018 р.). 2. Відсутність кваліфікованих фахівців і лікарів. 3. Проблема фінансового забезпечення та відсутність умов у приміщеннях для дітей та осіб з інвалідністю.

Директор Чортківського міського комунального центру комплексної реабілітації осіб з інвалідністю «Дорога в життя» I. І. Григораш звернула увагу на такі труднощі, як: 1 . Неготовність школи та вчителів до організації інклюзивного навчання. 2. Страх батьків. 3. Низька інформованість про переваги інклюзії.

Депутат Чортківської міської ради п'яти скликань, голова постійної комісії з питань бюджету Чортківської міської ради Л. О. Махомет відзначив такі проблеми: 1. Відсутність якісних пандусів, відповідних дверей, спеціально обладнаних туалетів і умивальників, наявність порогів. 2. Недостатне матеріально-технічне забезпечення спеціальним та допоміжним навчальним обладнанням європейського рівня. 3. Архітектурна доступність не вище першого поверху.

Таким чином, експерти виокремили найбільші, на їхній погляд, труднощі у забезпеченні інклюзивної складової - чотири з п'яти експертів вважають викликом для дітей з особливими потребами архітектурну недосконалість будівель, споруд, прилеглих територій, які їм доводиться відвідувати, в яких не враховані чи частково враховані потреби цих дітей. Троє з п’яти експертів стурбовані низькою інформованістю суспільства про переваги інклюзії $\mathrm{i}$, як наслідок, неготовністю батьків, вчителів, персоналу шкіл і загалом суспільства до належного сприйняття осіб з особливими потребами, створення комфортних умов навчання разом з однолітками. Стільки ж експертів висловили стурбованість відсутністю фахівців в освіті, медицині, інклюзивноресурсних центрів та недостатністю фінансування, що призводить до неналежного матеріально-технічного забезпечення навчальних закладів та їх недоступності для дітей з особливими потребами. На запитання «Які заходи доцільно було б здійснити органам центральної влади для забезпечення рівних можливостей особам з особливими потребами?» ми отримали такі відповіді:

С. В. Хом'як: 1. Забезпечити безплатний та облаштований транспорт для зручного пересування осіб з інвалідністю. 2. Сприяти доступності пришкільних територій: наявності під'їздів, паркувальних місць для осіб з інвалідністю, зокрема для підвезення дітей на візках, обладнаних спортивних майданчиків для дітей з інвалідністю.

I. М. Гулька: 1. Виділити цільові кошти для забезпечення архітектурної доступності для дітей 3 особливими потребами. 2. Збільшити ресурси для покращення матеріально-технічного забезпечення. 3. Здійснювати просвітницьку роботу в суспільстві та формувати відповідну суспільну, громадську думку стосовно інклюзії.

Т. Є. Дубина запропонувала органам центральної влади: 1. Створити умови для реалізації програми «Гроші йдуть за дитиною», відповідно до якої у батьків та дитини буде право обирати заклад, тож благодійні, приватні структури отримають можливість розвиватися і працювати. 2. Збільшити кількість практичних годин на корекційні заняття для кращого розвитку дітей.

I. I. Григораш першочерговими завданнями центральної влади вважає: 1. Широку просвітницьку 
роботу. 2. Обладнання школи для забезпечення безбар’єрного доступу. 3. Підготовку адміністрації закладу та педагогів.

Л. О. Махомет пропонує: 1 . Передбачати в бюджетах розвитку відповідні кошти на заходи. 2. Повноцінне функціонування ІРЦ з охопленням кожної дитини, яка потребує допомоги, особливо в селах. 3. Збільшення квот на держзамовлення для студентів з особливими потребами та їх подальше працевлаштування.

Аналіз експертних пропозицій щодо необхідних вдосконалень для потреб батьків і дітей на місцевому рівні свідчить про спільну позицію експертів щодо необхідності організації як навчання, так і дозвілля дітей з особливими потребами, позашкільної роботи спільно з їх однолітками. Актуальним, на думку експертів, $є$ і включення батьків дітей 3 особливими потребами в робочі групи, комісії, в штати установ, які надають допомогу дітям з особливими потребами, як таких, що зможуть надати якісні пропозиції щодо вдосконалення організації роботи з особливими дітьми.

Експертна оцінка перспектив розвитку інклюзивної освіти у Чортківському районі дозволяє сформувати практичні рекомендації для органів державної влади і місцевого самоврядування щодо оптимізації заходів з побудови освітнього інклюзивного простору та виокремлення першочергових завдань як для місцевої, так і для центральної влади.

Висновки та перспективи подальших досліджень. Низка різнопланових нормативних документів, цілеспрямоване фінансування, створення інклюзивно-ресурсних центрів, використання методик, апробованих на міжнародному рівні, підготовка тренерів, психологів, асистентів, підвищення кваліфікації вчителів, створення інклюзивного освітнього середовища - ці та інші фактори дозволяють ставити питання про системні, якісні зміни. У той же час актуальними залишаються проблеми підвищення рівня педагогічної культури батьків, ефективна співпраця педагогічних колективів 3

\section{Список літератури}

1. Вихрущ А. В. Концепт «здоров'я» в сучасній науці / А. В. Вихрущ, М. І. Руденко, І. Д. Драч // Актуальні питання гуманітарних наук : міжвузівський зб. наук. праць молодих вчених Дрогобицького державного педагогічного університету імені I. Франка. - Дрогобич, 2020. - Вип. 29. - С. 55-63. батьками, координація зусиль органів місцевого самоврядування, церкви, громадськості для створення сприятливого середовища для людей 3 iнвалідністю, в тому числі і для дітей з особливими потребами. У сучасних умовах зростає увага європейських педагогів до питань агресивної поведінки на індивідуальному рівні (булінг), та колективної агресії до особистості (мобінг). Цю проблему доцільно розглянути на дещо вищому рівні. Маємо на увазі агресію щодо дітей з особливими освітніми потребами, однокласників, батьків. Сучасні вчені все більшу увагу звертають на відмінності у вихованні хлопців і дівчат. Діти з особливими освітніми проблемами не $€$ винятком.

Необхідно переглянути зміст нормативних документів. Наприклад, згідно із сучасними міжнародними нормативно-правовими документами, діти 3 особливими освітніми потребами - це особи віком до 18 років, які потребують підтримки в освітньому процесі (діти з інвалідністю; діти з порушеннями психофізичного розвитку; діти-мігранти; діти, які працюють; діти-біженці; представники релігійних та національних меншин; діти із сімей з низьким прожитковим мінімумом; діти-сироти; діти із захворюванням на СНІД/ВІЛ та інші) [5]. На нашу думку, таке хаотичне поєднання потребує критичної оцінки.

Специфіка респондентів обмежує можливості вивчення думки учнів з особливими освітніми проблемами. У той же час варто значно більшу увагу звернути на вивчення думки викладачів, студентів педагогічних університетів, учителів щодо ефективності навчально-виховного процесу.

Окремого дослідження потребує готовність лікарів до вирішення окреслених проблем. Необхідно переглянути зміст окремих навчальних предметів у медичних університетах (українська мова за професійним спрямуванням), акцентувати увагу на розвитку емпатії, вмінні вести діалог, створювати ситуацію успіху для пацієнта.

2. Вихрущ А. В. Освітня політика Польщі (діти здорові та з особливими потребами) / А. В. Вихрущ // Молодь і ринок. - 2020. - № 2 (181). - С. 18-23.

3. Дічек Н. П. Розвиток В. О. Сухомлинським індивідуалізованого підходу до важких дітей (етико-педагогічний аспект) / Н. П. Дічек // Науковий вісник МДУ 
імені В. О. Сухомлинського. - 2014. - Вип. 1. 46 (108). Педагогічні науки. - С. 50-55.

4. Проєкт національної стратегії розвитку інклюзивної освіти на 2020-2030 роки / Міністерство освіти України. - URL : https://mon.gov.ua/ua/news/mon-rozrobilostrategichni-napryami-rozvitku-inklyuzivnoyi-osviti-do2030-roku.

5. Садова I. І. Інклюзія у закладах загальної середньої освіти України: тенденції розвитку : монографія / I. I. Садова. - Дрогобич : Посвіт, 2020. - 448 с.

\section{References}

1. Vykhrushch, A.V., Rudenko, M.I., Drach, I.D. (2020). Kontsept «zdorovia» v suchasnii nautsi [The concept of «health» in modern science]. Aktualni pytannia humanitarnykh nauk: mizhvuzivskyi zbirnyk naukovykh prats molodykh vchenykh Drohobytskoho derzhavnoho pedahohichnoho universytetu imeni I. Franka - Current Issues of the Humanities: Interuniversity Collection of Scien. Works of Young Scientists of Drohobych State Pedagogical University named after I. Franko. Drohobych [in Ukrainian].

2. Vykhrushch, A.V. (2020). Osvitnia polityka Polshchi (dity zdorovi ta z osoblyvymy potrebamy) [Polish education policy (children are healthy and with special needs)]. Molod i rynok - Youth and Market, 2 (181), 18-23 [in Ukrainian].

3. Dichek, N.P. (2014). Rozvytok V.O. Sukhomlynskym indyvidualizovanoho pidkhodu do vazhkykh ditei (etykopedahohichnyi aspekt) [Development of V.O. Sukhomlynskyi individualized approach to difficult children (ethical and pedagogical aspect)]. Naukovyi visnyk MDU imeni V. O. Sukhomlynskoho. Pedahohichni nauky-Scientific Bulletin of MSU named after V.O. Sukhomlynskyi. Pedagogical Sciences, 1, 46 (108), 50-55 [in Ukrainian].

4. Proiekt natsionalnoi stratehii rozvytku inkliuzyvnoi osvity na 2020-2030 roky [Draft of the national strategy
6. Федько О. А. Багатоаспектність поняття здоров’я у сучасній науковій думці / О. А. Федько // Державне управління: удосконалення та розвиток. - 2009. - № 4. URL : http: // www.dy. nayka. com.ua.

7. Blumsztajn A. Raport o kapitale intelektualnym Polski / A. Blumsztajn, M. Dąbrowska, Sz. Figiel. Warszawa, 2008. - $154 \mathrm{~s}$.

8. Marat E. Rodzina z dzieckem niepełnosprawnym. W ks. I. Janicka, H. Liberska Psychologia rodziny. - Warszawa : Wydawnictwo Naukowe PWN SA, 2014. - 682 s.

for the development of inclusive education for 2020-2030]. Ministerstvo osvity Ukrainy - Ministry of Education of Ukraine. Retrieved from: https://mon.gov.ua/ua/news/ mon-rozrobilo-strategichni-napryami-rozvitku-inklyuzivnoyi-osviti-do-2030-roku (datazvernennia: 22.09.2020) [in Ukrainian].

5. Sadova, I.I. (2020). Inkliuziia u zakladakh zahalnoi serednoi osvity Ukrainy: tendentsii rozvytku: monohrafiia [Inclusion in general secondary education institutions of Ukraine: development trends: monograph]. Drohobych: Posvit [in Ukrainian].

6. Fedko, O.A. (2009). Bahatoaspektnist poniattia zdorovia u suchasnii naukovii dumtsi [The multifaceted nature of the concept of health in modern scientific thought]. Derzhavne upravlinnia: udoskonalennia ta rozvytok. Retrieved from: http: // www.dy. nayka. com.ua.(data zvernennia 29.10.2020) [in Ukrainian].

7. Blumsytajn, A., Dąbrowska, M., Figiel, Sz. (2008). Raport o kapitale intelektualnym Polski. Warszawa.

8. Marat, E. (2014). Rodzina zdzieckem-niepełnosprawnym. W ks. Janicka I, Liberska H. Psychologia rodziny. Warszawa: Wydawnictwo Naukowe PWN SA. 